\title{
PENDIDIKAN KARAKTER DI MADRASAH SALAFIYAH
}

\author{
Fihris Sa'adah \\ IAIN Walisongo Semarang \\ e-mail: fihris@yahoo.com
}

\begin{abstract}
Theoretically, one of the dominant factors that influence the development of individual character are environmental factors which is a condition that allows the process of personal character development. Creating an conducive environment to the development of character Grikusumo Salaf Islamic School students is done by creating a tradition /habituation practical in everyday life in all their daily activities in relation to the quality of their religious or otherwise. Attempt the formation of character through this Salaf Islamic school in addition to the above character education, can also be done simultaneously through the educational value of the following steps. First, apply a "modeling" or "exemplary" or "uswah hasanah". Second, efforts to explain or clarify to students constantly about the value of good and evil has been done in the Girikusumo Salaf Islamic School. Third, implement the SIS is based on character education.
\end{abstract}

\begin{abstract}
$* * *$
Secara teoritik, salah satu faktor dominan yang mempengaruhi perkembangan karakter individu adalah faktor-faktor lingkungan yang merupakan kondisi yang memungkinkan proses perkembangan karakter pribadi. Menciptakan lingkungan yang kondusif bagi perkembangan karakter di kalangan siswa Sekolah Islam Salaf Girikusumo dilakukan dengan cara menciptakan tradisi atau praktek pembiasaan dalam kehidupan sehari-hari yang terkait dengan peningkatan kualitas keagamaan atau kehidupan mereka. Di samping upaya di atas, pembentukan karakter juga dilakukan dengan simultan melalui penanaman nilai dengan langkah-langkah sebagai berikut: pertama, menerapkan pencontohan atau uswah hasanah. Kedua menjelaskan tentang nilai yang baik dan buruk. Ketiga, mengimplementasikan SIS yang didasarkan pada pendidikan karakter.
\end{abstract}

Keywords: pendidikan, karakter, madrasah, salaf 


\section{A. Pendahuluan}

Secara legal formal character building menjadi tujuan Pendidikan Nasional, namun realitas sosial-kependidikan kita menunjukkan rapuhnya karakter output maupun outcome dari sistem pendidikan kita. Aksi tawuran antar siswa maupun antar mahasiswa, maraknya pergaulan bebas di kalangan siswa dan mahasiswa, pola-pola demonstrasi mahasiswa-pelajar yang anarkis, dan tentunya praktek korupsi di negeri ini yang tetap tumbuh subur adalah potret faktual yang menggambarkan rapuhnya karakter produk dari Sistem Pendidikan Nasional.

Fakta tersebut di atas secara tidak langsung menunjukkan bahwa ada sesuatu yang problematis (something problem) dalam Sistem Pendidikan Nasional, karena terjadi kesenjangan antara idealitas Undang-Undang Sisdiknas dengan realitas pendidikan di lapangan. Apakah problem tersebut terletak pada pelaksanaan pendidikannya-materi, pola maupun metode pendidikan-atau sistem pendidikannya, merupakan persoalan yang menarik untuk dikaji.

Pada prakteknya, pendidikan karakter yang diajarkan di sekolah umum selama ini hanya berbentuk konseling oleh guru Bimbingan dan Penyuluhan (BP), dan belum menyentuh secara optimal dalam kurikulum. Peran Guru BP, menurut Anita Lie, bahkan sangat terbatas karena tidak bisa meraih semuanya sehari-hari di sekolah. Selain itu, tidak jarang keberadaan guru BP dirangkap oleh guru mata pelajaran, sehingga konsep dan model pendidikan karakter di sekolah umum sampai sejauh ini tidak pernah optimal. ${ }^{1}$

Salah satu model pendidikan karakter yang diyakini efektif oleh banyak kalangan sekarang ini adalah model pendidikan "madrasah berbasis pesantren" atau boarding school ${ }^{2}$ dengan beragam variasinya sebagai sistem pendidikan tertua dalam sejarah pendidikan negeri ini. Sistem pendidikan ini bukan saja memberikan pengetahuan kognitif kepada santri, tetapi juga sekaligus bersama-sama belajar membudayakan ilmu dalam kehidupan sehari-hari, suatu kombinasi antara ilmu pengetahuan (sciences) dan budaya (culture), antara learning to know dengan learning to do.

1 http://www.serambinews.com/news/view/29630/tasawuf-pendidikan

2 http://www.serambinews.com/news/view/29630/tasawuf-pendidikan 
Kajian tentang "Pendidikan Karakter" dalam pendidikan Madrasah Salafiyah yang memiliki basis tarekat, hemat peneliti menarik diteliti karena dua alasan yang melatarinya. Karena, di samping — secara teoritik-tasawuf atau spiritualitas Islam merupakan bagian dari ilmu keislaman yang sarat dengan ajaran nilai-nilai moral Islam yang menjadi keniscayaan dalam pendidikan karakter, juga pendidikan karakter itu juga nampak dalam tujuan tasawuf itu sendiri sebagai ilmu yang menekankan kesucian diri dan hati dari segala sifat yang tercela ${ }^{3}$, melainkan juga terpancar dalam struktur konsep maqāmat ${ }^{4}$ sebagai tahapan atau tingkatan moralitas yang harus ditempuh oleh seorang murid sufi.

\section{B. Konsepsi Pendidikan Karakter}

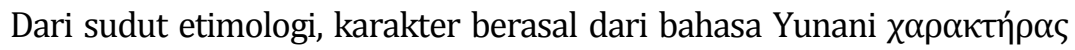
yang berarti "to mark" atau menandai dan memfokuskan bagaimana mengaplikasikan nilai kebaikan dalam bentuk tindakan atau tingkah laku, sehingga orang yang tidak jujur, kejam, rakus dan perilaku jelek lainnya dikatakan orang berkarakter jelek. Sebaliknya, orang yang perilakunya sesuai dengan kaidah moral disebut dengan berkarakter mulia. Sedangkan dari segi istilah, karakter sering dipandang sebagai cara berpikir dan berperilaku yang menjadi ciri khas tiap individu untuk hidup dan bekerjasama, baik dalam lingkup keluarga, masyarakat, bangsa dan negara. Individu yang berkarakter baik adalah individu yang bisa membuat keputusan dan siap mempertanggungjawabkan setiap akibat dari keputusan yang ia buat. ${ }^{5}$ Adapun berkarakter adalah berkepribadian, berperilaku, bersifat, bertabiat, dan berwatak". Karakter mengacu kepada serangkaian sikap (attitudes), perilaku (behaviors), motivasi (motivations), dan keterampilan (skills).

Dalam hal ini, karakter mulia berarti individu memiliki pengetahuan tentang potensi dirinya, yang ditandai dengan nilai-nilai seperti reflektif, percaya diri, rasional, logis, kritis, analitis, kreatif dan inovatif, mandiri, hidup sehat, bertanggung jawab, cinta ilmu, sabar, berhati-hati, rela berkorban,

3 Abu Bakar Muhammad bin Ishaq al-Kalabadzi, al-Ta'aruf li Madzhab Ahl al-Tasawwuf, (Beirut-Libanon: Dar al-Kutub al-'Ilmiyah, 1993/1413 H.), h. 10.

${ }^{4}$ Lihat: Safrodin Halimi, Spiritualitas Muhammad, Tinjauan Ontologi dan Psikologi, (Semarang: Mediatama Putra, 2005), h. 156.

${ }^{5} \mathrm{http}: / /$ www.jurnalnet.com/konten.php?nama=popular\&topik=10\&id=167 
pemberani, dapat dipercaya, jujur, menepati janji, adil, rendah hati, malu berbuat salah, pemaaf, berhati lembut, setia, bekerja keras, tekun, ulet/gigih, teliti, berinisiatif, berpikir positif, disiplin, antisipatif, inisiatif, visioner, bersahaja, bersemangat, dinamis, hemat/efisien, menghargai waktu, pengabdian/dedikatif, pengendalian diri, produktif, ramah, cinta keindahan (estetis), sportif, tabah, terbuka, tertib. Individu juga memiliki kesadaran untuk berbuat yang terbaik atau unggul, dan individu juga mampu bertindak sesuai potensi dan kesadarannya tersebut. Karakteristik adalah realisasi perkembangan positif sebagai individu (intelektual, emosional, sosial, etika, dan perilaku).

Terma tersebut bila dirangkai dengan terma pendidikan, maka dapat dimaknai dengan beragam pengertian, sekalipun secara subtantif itu sebenarnya sama. Di antaranya ada yang mengartikan pendidikan karakter sebagai pendidikan budi pekerti plus, yaitu yang melibatkan aspek pengetahuan (cognitive), perasaan (feeling), dan tindakan (action). Menurut Thomas Lickona, tanpa ketiga aspek ini, maka pendidikan karakter tidak akan efektif. Sementara itu, menurut Pusat Bahasa Depdiknas pendidikan karakter diartikan sebagai "bawaan, hati, jiwa, kepribadian, budi pekerti, perilaku, personalitas, sifat, tabiat, temperamen, watak".

Pendidikan karakter adalah suatu sistem penanaman nilai-nilai karakter kepada warga sekolah yang meliputi komponen pengetahuan, kesadaran atau kemauan, dan tindakan untuk melaksanakan nilai-nilai tersebut. Pendidikan karakter dapat dimaknai sebagai "the deliberate use of all dimensions of school life to foster optimal character development". Dalam pendidikan karakter di sekolah, semua komponen (pemangku pendidikan) harus dilibatkan, termasuk komponen-komponen pendidikan itu sendiri, yaitu isi kurikulum, proses pembelajaran dan penilaian, penanganan atau pengelolaan mata pelajaran, pengelolaan sekolah, pelaksanaan aktivitas atau kegiatan kokurikuler, pemberdayaan sarana prasarana, pembiayaan, dan ethos kerja seluruh warga sekolah/lingkungan. Di samping itu, pendidikan karakter dimaknai sebagai suatu perilaku warga sekolah yang dalam menyelenggarakan pendidikan harus berkarakter.6

${ }^{6}$ Ibid. 
Menurut David Elkind \& Freddy Sweet Ph.D. (2004), pendidikan karakter dimaknai sebagai berikut:

"Character education is the deliberate effort to help people understand, care about, and act upon core ethical values. When we think about the kind of character we want for our children, it is clear that we want them to be able to judge what is right, care deeply about what is right, and then do what they believe to be right, even in the face of pressure from without and temptation from within."

Pendidikan karakter memiliki esensi dan makna yang sama dengan pendidikan moral dan pendidikan akhlak. Tujuannya adalah membentuk pribadi anak, supaya menjadi manusia yang baik, warga masyarakat, dan warga negara yang baik. Adapun kriteria manusia yang baik, warga masyarakat yang baik, dan warga negara yang baik bagi suatu masyarakat atau bangsa, secara umum adalah nilai-nilai sosial tertentu, yang banyak dipengaruhi oleh budaya masyarakat dan bangsanya. Oleh karena itu, hakikat dari pendidikan karakter dalam konteks pendidikan di Indonesia adalah pedidikan nilai, yakni pendidikan nilai-nilai luhur yang bersumber dari budaya bangsa Indonesia sendiri, dalam rangka membina kepribadian generasi muda.

Dengan demikian, pendidikan karakter senantiasa mengarahkan diri pada pembentukan individu bermoral, cakap mengambil keputusan yang tampil dalam perilakunya, sekaligus mampu berperan aktif dalam membangun kehidupan bersama. Singkatnya, bagaimana membentuk individu yang menghargai kearifan nilai-nilai lokal sekaligus menjadi warganegara dalam masyarakat global dengan berbagai macam nilai yang menyertainya.

\section{Pendidikan Karakter dalam Pendidikan Islam}

Dalam Kumpulan Hasil-hasil Kongres Umat Islam Indonesia, ${ }^{8}$ disebutkan bahwa pendidikan karakter merupakan langkah penting dan strategis dalam membangun kembali jati diri individu mapaun bangsa. Tetapi penting untuk segara dikemukakan bahwa pendidikan karakter haruslah melibatkan semua pihak; rumahtangga dan keluarga; sekolah; dan lingkungan sekolah lebih luas (masyarakat). Karena itu, langkah pertama yang harus dilakukan adalah menyambung kembali hubungan dan educational networks yang nyaris

\footnotetext{
${ }^{7}$ Ibid.

${ }^{8}$ Kumpulan Hasil-hasil Kongres Ummat Islam Indonesia: Menyongsong Era Indonesia Baru, (Jakarta: MUI, 1998).
} 
terputus antara ketiga lingkungan pendidikan ini. Pembentukan watak dan pendidikan karakter tidak akan berhasil selama antara ketiga lingkungan pendidikan tidak ada kesinambungan dan harmonisasi. Dengan demikian, rumahtangga dan keluarga sebagai lingkungan pembentukan watak dan pendidikan karakter pertama dan utama mestilah diberdayakan kembali. Keluarga hendaklah kembali menjadi "school of love," sekolah untuk kasih sayang. Dalam perspektif Islam, keluarga sebagai "school of love" dapat disebut sebagai "madrasah mawaddah wa rahmah, tempat belajar yang penuh cinta sejati dan kasih sayang.

Dalam hal ini, tanpa perlu diungkapkan panjang lebar, Islam telah memberikan perhatian yang sangat besar kepada pembinaan keluarga (usrah). Keluarga merupakan basis dari ummah (bangsa); dan karena itu keadaan keluarga sangat menentukan keadaan ummah itu sendiri. Bangsa terbaik (khair ummah) yang merupakan ummah wähidah (bangsa yang satu) dan ummah wasath (bangsa yang moderat), sebagaimana dicita-citakan Islam hanya dapat terbentuk melalui keluarga yang dibangun dan dikembangkan atas dasar mawaddah wa rahmah. ${ }^{9}$

Berdasarkan sebuah hadits yang diriwayatkan Anas ra., keluarga yang baik memiliki empat ciri. Pertama; keluarga yang memiliki semangat (ghïrah) dan kecintaan untuk mempelajari dan menghayati ajaran-ajaran agama dengan sebaik-baiknya untuk kemudian mengamalkan dan mengaktualisasikannya dalam kehidupan sehari-hari. Kedua, keluarga di mana setiap anggotanya saling menghormati dan menyayangi; saling asah dan asuh. Ketiga, keluarga yang dari segi nafkah (konsumsi) tidak berlebih-lebihan; tidak ngoyo atau tidak serakah dalam usaha mendapatkan nafkah; sederhana atau tidak konsumtif dalam pembelanjaan. Keempat, keluarga yang sadar akan kelemahan dan kekurangannya; dan karena itu selalu berusaha meningkatkan ilmu dan pengetahuan setiap anggota keluarganya melalui proses belajar dan pendidikan seumur hidup (life long learning), min al-mahdi ila allahdi. ${ }^{10}$

${ }^{9}$ M. Quraish Shihab, Wawasan al-Qur'an: Tafsir Maudhu ì atas Pelbagai Persoalan Umat, (Bandung: Mizan, 1996), h. 56.

${ }^{10}$ Ibid. 
Sekolah, pada hakikatnya bukanlah sekedar tempat "transfer of knowledge" belaka. Seperti dikemukakan Fraenkel ${ }^{11}$ sekolah tidaklah semata-mata tempat di mana guru menyampaikan pengetahuan melalui berbagai mata pelajaran. Sekolah juga adalah lembaga yang mengusahakan usaha dan proses pembelajaran yang berorientasi pada nilai (value-oriented enterprise). Lebih lanjut, Fraenkel mengutip John Childs yang menyatakan, bahwa organisasi sebuah sistem sekolah dalam dirinya sendiri merupakan sebuah usaha moral (moral enterprise), karena ia merupakan usaha sengaja masyarakat manusia untuk mengontrol pola perkembangannya. ${ }^{12}$

Pembentukan watak dan pendidikan karakter melalui sekolah, dengan demikian, tidak bisa dilakukan semata-mata melalui pembelajaran pengetahuan, tetapi adalah melalui penanaman atau pendidikan nilai-nilai. Apakah nilai-nilai tersebut? Secara umum, kajian-kajian tentang nilai biasanya mencakup dua bidang pokok, estetika, dan etika (atau akhlak, moral, budi pekerti).

Estetika mengacu kepada hal-hal tentang dan justifikasi terhadap apa yang dipandang manusia sebagai "indah", apa yang mereka senangi. Sedangkan etika mengacu kepada hal-hal tentang dan justifikasi terhadap tingkah laku yang pantas berdasarkan standar-standar yang berlaku dalam masyarakat, baik yang bersumber dari agama, adat istiadat, konvensi, dan sebagainya. Dan standar-standar itu adalah nilai-nilai moral atau akhlak tentang tindakan mana yang baik dan mana yang buruk.

Lingkungan masyarakat luas jelas memiliki pengaruh besar terhadap keberhasilan penanaman nilai-nilai estetika dan etika untuk pembentukan karakter. Dari perspektif Islam, menurut Quraish Shihab, situasi kemasyarakatan dengan sistem nilai yang dianutnya, mempengaruhi sikap dan cara pandang masyarakat secara keseluruhan. Jika sistem nilai dan pandangan mereka terbatas pada "kini dan di sini", maka upaya dan ambisinya terbatas pada kini dan di sini pula. ${ }^{13}$

11 Fraenkel, Jack R., How to Teach about Values: An Analytical Approach, (Englewood, NJ: Prentice Hall, 1977), h. 1-2.

12 Ismail, Taufiq, et al., Drh., H., Membangun Kemandirian Umat di Pedesaan, (Bogor: Pesantren Pertanian Darul Fallah, 2000).

${ }^{13}$ Quraish Shihab, Wawasan al-Qur'an..., h. 321. 
Dalam konteks itu, al-Qur'an dalam banyak ayatnya menekankan tentang kebersamaan anggota masyarakat menyangkut pengalaman sejarah yang sama, tujuan bersama, gerak langkah yang sama, solidaritas yang sama. Di sinilah, tulis Quraish Shihab, muncul gagasan dan ajaran tentang amar ma'rüf dan nahy munkar; dan tentang farḍu kifāyah, tanggung jawab bersama dalam menegakkan nilai-nilai yang baik dan mencegah nilai-nilai yang buruk.

\section{Sejarah Singkat Madrasah Islam Salafiyah Girikusumo}

Madrasah Islam Salafiyah Girikusumo lebih dikenal dengan nama Sekolah Islam Salaf. Istilah "sekolah" bukan "madrasah" dalam penamaan ini menjadi sesuatu yang relatif jarang berlaku, terutama bagi sekolah-sekolah yang ada dalam lingkup pesantren. Sebab, umumnya tradisi pesantren lebih familier dengan terma "madrasah" yang lebih "Islami-Arabis" daripada terma "sekolah" yang terkesan nasionalis dan terjemahan dari school, warisan bahasa penjajah. Nampaknya, penamaan ini secara implisit mengandung tujuan agar kelak sekolah ini selain memberikan bekal pendidikan Islam salaf, juga secara modern mampu menjawab dan mengatasi persoalan-persoalan nasional modern. Sekolah bisa disebut sebagai bagian dari akibat pertauatan antara tradisi Islam Salaf dengan tradisi modern yang telah berkembang di masyarakat waktu itu.

Sekolah Islam Salafiyah Girikusumo didirikan oleh K.H. Nadzif Zuhri (w. 2000 M.), cucu dari Syekh Muhammad Hadi pada tahun 1986 M.14 sekalipun menurut versi lain disebutkan bahwa Sekolah Islam Salaf ini didirikan sekitar tahun $1288 \mathrm{H}$. oleh K.H. Muhammad Hadi bersamaan dengan berdirinya Pondok Pesantren Girikusumo, namun sesungguhnya timing berdirinya Sekolah Islam Salaf itu melalui proses kronologis yang cukup panjang setelah berdirinya Pondok Pesantren Giri sebagai pengembangan dari lembaga Madrasah sebelumnya. Tetapi, ide dan istilah "Sekolah Islam Salaf" itu baru muncul pada masa K.H. Nadzif Zuhri sekitar tahun 1986.

Sekolah Islam Salafiyah ini merupakan pengembangan dari Madrasah Falakiyah yang telah dirintis oleh K.H. Muhammad Zuhri, ayah K.H. Nadzif Zuhri. Sepulang dari studi ilmu agama di salah satu Universitas di Madinah

\footnotetext{
${ }^{14}$ Reportase ini ditulis berdasarkan dokumen Pesantren Girikusumo yang disusun oleh Musni Husnan, S.Ag. pada tahun 2008.
} 
pada tahun 1985, K.H. Nadzif Zuhri membawa ide pengembangan-kalau bukan disebut perubahan-bagi proses kegiatan belajar mengajar (KBM) di pondok pesantren dan lembaga pendidikan yang berada di bawah naungannya. Madrasah Falakiyah yang sistem pendidikannya menganut sistem klasikal oleh beliau sistem penyajian materi mata pelajarannya lebih dipertajam lagi.

Pada mulanya ide pengembangan dan perubahan yang dihembuskan oleh K.H. Nadzif saat itu dinilai cukup kontroversial dan sempat menyebabkan khawatir sebagian masyarakat sekitarnya. Mereka khawatir bahwa ide tersebut bisa mengakibatkan nilai-nilai salaf yang telah mapan di lingkungan pondok pesantren akan hilang. Namun, dengan keyakinan dan kepiawaiannya dalam merealisasikan ide dan gagasan pengembangannya itu, ia justru dirasa semakin mempertegas eksistensi, arah dan tujuan pondok pesantren salaf tersebut, yakni sebuah institusi pendidikan Islam yang memiliki visi tidak terbatas pada membentuk manusia yang berilmu dan berakhlak, tetapi juga sekaligus mampu mengantisipasi persoalan-persoalan yang berkembang di masyarakat dari masa ke masa.

Melalui Sekolah Islam Salaf, K.H. Nadzif mencoba menata ulang kembali lembaga pendidikan formal yang sudah ada waktu itu dengan menetapkan sistem baru. Madrasah yang telah ada dijadikan cikal bakal keberadaan SIS. Sistem pendidikan yang sudah berjalan dibenahi dan ditata kembali.

Ini bukan berarti Pondok Pesantren Giri yang telah berusia seabad lebih mengalami pergeseran tujuan dan orientasi. Karena, di sini ciri-ciri Pesantren Salaf sebagai lembaga pendidikan yang mengajarkan dan menanamkan mentalitas dan karakter kemandirian, keberanian pantang menyerah serta "menderita" dalam usaha mencapai tujuan, memiliki ketelitian dan kemampuan yang unggul dalam bahasa Arab dengan beragam ilmu alatnya, tetap dipertahankan. Pengembangan Sekolah Islam Salaf ini oleh banyak kalangan justru semakin mempertegas ciri-ciri kesalafan tersebut, yakni ciriciri yang telah banyak terdistorsi dalam pola pendidikan pesantren modern belakangan ini.

Sebagai sebuah lembaga pendidikan formal di lingkungan pondok pesantren, kegiatan Sekolah Islam Salaf dimanaj sedemikian rupa, mulai dari desain perencanaan materi yang diajarkan hingga tujuan akhir, sesuatu yang sebelumnya nyaris tidak tersentuh oleh para pengelola pondok pesantren 
umumnya. Ide-ide penataan ulang tersebut dapat dilihat misalnya, pada sistem perjenjangan santri yang masa pendidikannya dibatasi hanya delapan tahun khususnya bagi santri yang ketika masuk telah memiliki bekal penguasaan dasar-dasar ilmu agama, dan sembilan tahun bagi calon santri yang tidak memiliki bekal penguasaan dasar-dasar ilmu agama yang memadai. Tambahan masa satu tahun tersebut diperuntukkan bagi program penyesuaian atau persiapan (isti'dād) sebelum masuk kelas satu SIS.

Sebab itulah, dalam proses rekrutmen siswa, Sekolah Islam Salaf memberlakukan tes ujian masuk sebagai sistem yang didesain untuk menentukan jenjang pendidikan (kelas) bagi masing-masing calon santri yang akan belajar di sana. Sistem tes masuk ini tentu saja merupakan sistem yang jarang ditemukan pada pesantren salaf pada umumnya, karena Kiai pengasuh biasanya secara terbuka mempersilahkan siapa pun yang ingin belajar di pesantrennya, tanpa melihat batasan umur maupun tingkat kecerdasan, sehingga mereka bebas menentukan materi apa saja yang dipelajarinya.

SIS ini boleh jadi merupakan salah satu langkah terobosan Pesantren Salaf dalam upaya mempertahankan dan sekaligus mengembangkan jati dirinya di tengah-tengah derasnya arus perubahan yang terjadi pada masyarakat modern tanpa kehilangan identitas kesalafannya. Melalui sistem kurikulum yang telah didesain sedemikian rupa oleh pengasuhnya, Sekolah Islam Salaf mencoba menawarkan suatu alternatif pendidikan yang dapat menjamin suatu Pesantren Salaf agar tetap mampu menelorkan para alumni yang dapat eksis di masyarakat dan mampu memberikan konstribusi penting bagi pembangunan bangsa dan negara.

Secara eksplisit, SIS ini memiliki beberapa tujuan, yaitu: (1) menyebarkan ajaran Islam ke seluruh umat; (2) mendidik para santri agar para santri agar berpegang teguh pada ajaran Islam, dengan berbekal ilmu pengetahuan dan keterampilan yang membuat mereka mampu berdakwah serta mampu memecahkan problematika umat menurut petunjuk al-Qur'an, sunnah Nabi saw, dan amal ulama salaf; (3) menanamkan semangat memiliki Islam dengan memberikan latihan-latikan praktis dan amalan konkrit dalam kehidupan individu maupun sosial yang didasarkan pada keikhlasan dengan megikuti jejak Rasulullah SAW dan ulama salaf. 


\section{E. Interelasi Madrasah Islam Salafiyah, Pondok Pesantren Salaf dan Pendidikan Thariqah al-Naqsabandiyah al-Khalidiyah}

Secara historis dan subtantif, Sekolah Islam Salaf (SIS) memiliki hubungan interelatif yang sangat kuat dengan berdirinya Pondok Pesantren Salaf Girikusumo maupun lembaga Thariqah al-Naqsabandiyah al-Khalidiyah yang berkembang di sana. Ketiga-tiganya memiliki hubungan saling mempengaruhi satu sama lain. Karena, secara historis munculnya SIS juga tidak lepas dari eksistensi Pondok Pesantren Salaf Girikusumo yang telah lebih dulu berdiri dan ditopang dengan pengajian Thariqah al-Naqsyabandiyah alKhalidiyah.

Ponpok Pesantren Salaf, Banyumeneng Mranggen Demak didirikan oleh Syekh Muhammad Hadi (W. 1931 M.), seorang Kiai sekaligus murshid Thariqah al-Naqsyabandiyah al-Khalidiyah pada tahun 1288 H./1868 M. Pondok pesantren ini merupakan perwujudan gagasan Syekh Muhammad Hadi untuk membangun sebuah lembaga pendidikan yang menangani pendidikan akhlak dan ilmu agama di tengah-tengah masyarakat. Penetapan tahun ini didasarkan pada informasi yang tertera dalam prasasti di dinding bagian depan bangunan masjid dengan tulisan Arab Pegon yang berbunyi:

"Iki pepenget masjid dukuh Girikusumo, tahun ba Hijriyah Nabi sallallahu 'alaihi wasallam 1228 wulan Rabi'ul Akhir tanggal ping nembelas awit jam songo dalu jam setunggal dalu rampung."

Sepeninggal Mbah Hadi atau Mbah Giri pada tahun 1931 M., amanat Ponpok Pesantren dipegang dan diteruskan oleh adiknya, K. Sirajudin atau K. Zahid (W.1967), dengan tetap mempertahankan sistem pendidikan akhlak dan agama, serta pengajian Thariqah Naqsyabandiyah Khalidiyah ala Mbah Hadi. Pada saat ini jumlah santri Pondok Pesantren terus bertambah. Demikian juga, ajaran Thariqah al-Naqasyabandiyah al-Khalidiyah juga mengalami penyebaran yang sedemikian pesat hingga luar Jawa, yang disebabkan oleh banyaknya para santri yang mengikuti program transmigrasi dari Jawa ke Kalimantan, Sumatera dan Sulawesi.

Pada tahun 1967 K. Zahid wafat, dan amanat pondok pesantren diteruskan oleh putra tertuanya, K.H. Muhammad Zuhri, yang lebih dikenal dengan sebutan Mbah Muh. Di era Mbah Muh inilah Pondok Pesantren Giri mulai melakukan pengembangan di bidang pendidikan santri. Sistem pendidikan yang selama ini berjalan dengan metode bandongan dilengkapi dengan 
sistem klasikal, yang kemudian diberi nama "Madrasah Falaqiyah". Dibentuknya sistem ini, ditengarai selain karena pengaruh dari perkembangan sistem pendidikan saat itu, juga untuk tujuan agar penyajian kitab-kitab klasik bisa sistematis dan untuk mempermudah para santri dalam memahami dan menguasai kajian kitab-kitab tersebut.

Pada tahun 1980 Mbah Muh wafat, dan amanat Pesantren Giri dipegang oleh putra bungsunya, K.H. Munif Zuhri dan saudaranya K.H. Nadzif Zuhri. Kedua saudara ini memiliki spesifikasi sendiri-sendiri. K.H. Munif Zuhri memiliki konsentrasi di bidang kepesantrenan dan dunia thariqah, sementara K.H. Nadzif waktu itu juga berpartisipasi dalam dunia politik nasional. Persentuhan K.H. Nadzif dengan dunia pesantren, pendidikan timur tengah, serta dunia politik nasional nampaknya sangat mempengaruhi munculnya ide pengembangan dan perubahan dari Madrasah Falaqiyah menjadi Sekolah Islam Salaf yang mencoba menyandingkan nilai-nilai salafiyah dengan tuntutan moderinitas.

Pada satu sisi, nilai-nilai salafiyah dalam tradisi pesantren salaf dan nilainilai akhlak tasawuf yang tercermin dalam tradisi Thariqah al-Naqsyabandiyah al-Khalidiyah tetap dijaga, pada sisi lain Sekolah Islam Salaf ini juga berupaya mengadopsi sebagian sistem pendidikan nasional modern yang bersifat klasikal. Bahkan, penamaan "sekolah" saat itu juga sangat mungkin didorong oleh kuatnya tuntutan modernitas yang telah berkembang sangat populer di kalangan masyarakat waktu itu, sehingga penamaan ini juga bisa disebut sebagai terjemahan dari bahasa market (marketable) yang lebih dikenal dan banyak diminati masyarakat.

Dalam tataran realitas, pengaruh figur para kiai pengasuh pondok pesantren Girikusumo dari Mbah Hadi hingga sekarang Mbah Munif Zuhri sebagai seorang ilmuwan agama sekaligus murshid besar al-Thariqah alNaqsyabandiyah al-Khalidiyah memiliki pengaruh besar dan bentukan kultur moral dan karakter para santrinya. Salah satu bangunan karakter santri yang dipengaruhi dari ketiga komponen itu adalah mentalitas santri yang secara ilmiyah getol dalam menggali dan mengaji ilmu agama dan bahasa, namun juga memiliki relasi hubungan dengan Kiai yang khas ala Tarekat layaknya seorang murid kepada murshid, sebuah pola hubungan yang penuh dengan sikap super tawādú. 


\section{F. Pendidikan Karakter di Madrasah Islam Salafiyah Girikusumo}

Dalam proses pendidikan, terbentuknya karakter siswa, secara teoritik, merupakan arti dan tujuan hakiki dari pendidikan itu sendiri, sebagaimana juga disampaikan Martin Luther King bahwa kecerdasan berkarakter merupakan tujuan akhir pendidikan yang sebenarnya (intelligence plus character... that is the goal of true education). ${ }^{15}$ Apa yang disampaikan Martin Luther mengenai urgensitas kecerdasan karakter sebagai tujuan akhir dari pendidikan, pada dasarnya, merupakan penjabaran dari missi risalah dari semua agama samawi.

Islam bahkan, secara eksplisit-tekstual-șarīh menyatakan bahwa missi terbesar dari agama ini adalah menyempurnakan kemuliaan karakter (makārim al-akhlāq), yakni membentuk kepribadian yang mulia yang mencerminkan kemuliaan akhlak yang luhur. Gagasan Islam teragung ini sudah secara berulang-ulang telah didengungkan, dicerna, dipahami dan dipraktekkan oleh para civitas akademika baik santri, ustadz, maupun pengelola dalam miniatur kehidupan di pesantren dan Sekolah Islam Salaf Girikusumo Mranggen Demak. Meminjam teori Thomas Lickona, setidaknya ada tiga proses pendidikan karakter santri di Sekolah Islam Girikusumo, yang melibatkan aspek pengetahuan (cognitive), perasaan (feeling), dan tindakan (action). Ketiga aspek ini diinternalisasikan dalam tradisi pendidikan Sekolah Islam Salaf dengan pendekatan knowing the good, feeling the good, dan acting the good.

\section{Proses Knowing The Good dan Feeling The Good}

Pembentukan karakter santri Sekolah Islam Salaf Girikusumo dimulai dari pengajaran kognitif mengenai nilai-nilai kebaikan dan akhlak yang mulia kepada mereka. Pengenalan dan pemahaman kognitif tentang nilai-nilai yang hendak dibentuk menjadi karakter santri dilakukan baik dalam program kegiatan belajar mengajar di sekolah maupun dalam program ekstra-kurikuler.

Dalam proses belajarn mengajar di intra sekolah, mata pelajaran akhlak berada dalam struktur kurikulum Sekolah Islam Salaf dalam setiap jenjangnya. Materi akhlak yang diajarkan meliputi akhlak yang tertera dalam kitab Ta'İm al-Muta'allim, Nașā'ih al-'Ibād, Ittihaf al-Sā'ilīn, Risālah al-Mudhakarah

${ }^{15} \mathrm{http}: / /$ charactercounts.org/training/cds-schedule.php 
hingga Fușuss al-'Ilmiyyah. Subtansi kajian semua kitab tersebut di atas merupakan kajian akhlak tasawuf yang menekankan pada kebersihan hati dan kesucian perilaku sekaligus dengan variasi yang beragam. Kitab Ta'lim alMuta'allim merupakan kitab yang mengajarkan beragam pondasi tatakrama dan adab seorang santri yang sedang mencari ilmu agar memperoleh cita-cita ilmu pengetahuan yang dinginkan dan ilmunya dapat bermanfaat. Pola relasi santri dengan sang guru juga telah diatur dan diajarkan sedemikian rupa, sehingga tercipta karakter santri yang "super" tawāḍ $u^{\prime}$ terhadap gurunya maupun yang lain. Pola relasi antar sesama teman juga dikaji sedemikian rupa dalam kitab tersebut. Pengajaran kitab ini yang disuguhkan kepada santri Sekolah Islam Salaf dapat dilihat sebagai sebuah proses pengenalan nilai-nilai luhur dalam karakter santri yang ideal.

Demikian juga, nilai-nilai luhur yang tertuang dalam Kitab Nașā'ih al'Ibād, Ittihhaf al-Sä'ilīn, Risālah al-Mudhakarah hingga Fușuṣ al-'Ilmiyyah menjadi bagian penting dalam proses pengenalan kognitif mengenai karakter yang luhur yang harus ditampilkan oleh para santri Sekolah Islam Salaf Girikusumo. Pengajaran ini-meminjam istilah Foerster-merupakan salah satu ciri dasar dalam pendidikan karakter di Sekolah Islam Salaf, di mana setiap tindakan diukur berdasar hierarki nilai dan nilai menjadi pedoman normatif setiap tindakan. Nilai-nilai yang terurai dalam referensi akhlak tasawuf tersebut melalui proses pengajaran hendak diperkenalkan, ditanamkan, diyakini dan dipedomani oleh santri dalam kehidupan mereka.

Pengenalan kognitif mengenai nilai-nilai karakter yang luhur juga tercermin dalam kegiatan ekstra-kurikuler di Sekolah Islam Salaf Girikusumo, karena para santri juga disuguhi kajian kitab yang berisi substansi akhlak tasawuf. Di antara kitab yang dikaji berkenaan dengan hal tersebut adalah kitab Hikam dan Adab Suluk al-Murid. Kajian nilai-nilai karakter yang tertuang dalam kedua kitab tersebut sangatlah mendalam. Karena selain menguraikan kesucian hati dan kesalihan perilaku mengupas juga dimensi ma'rifah. Karakter yang dibangun dalam kitab itu nampaknya adalah karakter seorang hamba Tuhan yang shalih zhahir dan batin, baik dalam hubungannya dengan Sang Tuhan maupun sesama manusia.

Proses knowing the good atau penanaman kognisi santri Sekolah Islam Salaf mengenai nilai-nilai kebaikan dalam proses pengajaran kitab-kitab akhlak-tasawuf tersebut di atas berjalan seiring dengan proses tumbuhnya 
spirit feeling loving the good, di mana mereka merasakan dan mencintai kebajikan menjadi engine yang bisa membuatnya senantiasa mau berbuat kebaikan tersebut. Sehingga tumbuh kesadaran bahwa mereka melakukan perilaku kebajikan tersebut karena mereka meyakini dan mencintai kebaikan tersebut. Dari situ, kebaikan itu menjadi kebiasaan atau dalam tataran acting the good.

Dimensi-dimensi yang termasuk dalam moral knowing sebagaimana tersebut dalam proses belajar mengajar di Madrasah Salafiyah Girikusumo, yang telah mengisi ranah kognitif santri adalah kesadaran moral (moral awareness), pengetahuan tentang nilai-nilai moral (knowing moral values), penentuan sudut pandang (perspective taking), logika moral (moral reasoning), keberanian mengambil sikap (decision making), dan pengenalan diri (self knowledge). Karakteri siswa yang ditempa dalam Madrasah Salafiyah ini tentu memiliki kekhasan tersendiri dibandingkan dengan siswa/siswi di sekolah pada umumnya. Dari moral knowing yang dialami para santri Sekolah Salaf ini, selanjutnya berkembang menjadi moral feeling, di mana perasaan dan kepekaan moral mereka sangat dipengaruhi dengan nilai-nilai moral religius yang dipelajari baik melalui pembelajaran, praktek maupun pembiasaan (habit).

Moral feeling merupakan penguatan aspek emosi santri Sekolah Salaf Girikusumo untuk menjadi manusia berkarakter sebagaimana insan kamil yang dicita-citakan dalam tradisi akhlak-tasawuf, atau manusia seutuhnya dalam istilah cita-cita bangsa Indonesia. Penguatan ini berkaitan dengan bentuk-bentuk sikap yang harus dirasakan oleh santri Sekolah Islam Salaf, yaitu kesadaran akan jati diri (conscience), percaya diri (self esteem), kepekaan terhadap derita orang lain (emphaty), cinta kebenaran (loving the good), pengendalian diri (self control), kerendahan hati (humility) yang telah ditanamkan kepada mereka. Hanya, nilai-nilai universal yang diajarkan dan ditanamkan dalam proses pembentukan karakter di SIS ini senantiasa berpijak dari prinsi-prinsip teologis-religius, bukan semata-mata berdasarkan atas pertimbangan logika. Perbedaannya terletak pada visi moral religius senantiasa tidak sekedar berjangka pendek untuk kepentingan kehidupan dunia, tetapi juga untuk kepentingan kehidupan akhirat yang lebih abadi. Sehingga, pola ini dinilai dapat menamkan moral feeling lebih dalam dibanding dengan pola lainnya. 
Hal ini didasari oleh kenyataan bahwa kebiasaan berbuat baik (habit) semata tidak selalu menjamin bahwa santri yang telah terbiasa tersebut secara sadar menghargai pentingnya nilai karakter (valuing) atau nilai-nilai moral tersebut. Karena mungkin saja perbuatannya tersebut dilandasi oleh rasa takut untuk berbuat salah, bukan karena tingginya penghargaan akan nilai itu. Misalnya ketika santri berbuat jujur hal itu dilakukan karena dinilai oleh orang lain, bukan karena keinginannya yang tulus untuk menghargai nilai kejujuran itu sendiri. Oleh karena itu dalam pendidikan karakter di SIS Girikusumo ditanamkan struktur amaliah yang harus sampai pada tahapan shukriyah dan ikhlāss.

Tahapan syukur ini menanamkan perasaan bahwa santri atau seseorang melakukan suatu kebaikan itu bukan karena takut sesuatu, melainkan karena ia perlu melakukannya sebagai kebutuhan akan syukurnya kepada tuhan. Sedangkan tahapan ikhlas itu menanamkan perasaan kepada santri bahwa ia melakukan kebaikan itu karena untuk kebaikan itu sendiri atau dalam istilah agama untuk Allah SWT, Sang Mahabaik itu sendiri, bukan untuk kepentingan lainnya. Dua hal ini merupakan domain sufistik yang berada dalam tingkat tertinggi dalam amal seorang hamba yang tentu saja pasti diken oleh para santri SIS dengan basis ilmu religius dan tasawuf ini.

Proses tersebut di atas ditanamkan kepada para santri SIS dalam rangka menumbuhkan aspek perasaan (domain affection atau emosi). Komponen ini dalam pendidikan karakter disebut dengan "desiring the good" atau keinginan untuk berbuat kebaikan. Pendidikan karakter yang baik dengan demikian harus melibatkan bukan saja aspek "knowing the good" (moral knowing), tetapi juga "desiring the good" atau "loving the good" (moral feeling), dan "acting the good" (moral action).

Dari moral feeling inilah kemudian terbentuk apa yang disebut moral action atau acting the good. Moral action merupakan perbuatan atau tindakan moral yang merupakan hasil (outcome) dari dua komponen karakter lainnya. Untuk memahami apa yang mendorong seseorang dalam perbuatan yang baik (act morally) maka harus dilihat tiga aspek lain dari karakter yaitu kompetensi (competence), keinginan (will), dan kebiasaan (habit).

Dalam bingkai teori ini, sesungguhnya dapat dikemukakan bahwa santri Sekolah Islam Salaf Girikusumo telah ditanamkan kompetensi atau keahlian serta pemahaman tentang nilai-nilai moral universal religius dengan beragam materi, kitab moral, nilai-nilai sufistik yang diajarkan kepada mereka. 
Pemahaman tersebut selanjutnya menumbuhkan kesadaran moral dan keinginan pada diri mereka untuk mempraktekkan nilai-nilai moral tersebut dalam kehidupan sehari-hari. Bahkan keinginan (will) mereka mestinya memiliki pijakan lebih kuat, karena bukan saja dilandasi kepentingan duniawi semata, melainkan juga untuk memperoleh kebahagiaan dan kesuksesan abadi di akhirat kelak, atau dalam bahasa tasawuf dilandasi juga dengan kesadaran akan kecintaannya dengan Allah SWT.

Pada tahap selanjutnya kesadaran moral semakin mengkristal di kalangan santri Sekolah Islam Salaf seiring dengan praktek-praktek moral yang telah menjadi kebiasaan (habit) dalam lingkungan Sekolah setiap hari. Hal inilah kemudian yang disebut sebagai proses acting the good.

\section{Penanaman Nilai-nilai Religius Universal (Proses Acting The Good)}

Secara teoritik, salah satu faktor dominan yang mempengaruhi proses perkembangan karakter individu adalah faktor lingkungan (environment) yang merupakan kondisi yang memungkinkan berlangsungnya proses perkembangan karakter seseorang. ${ }^{16}$ Membentuk lingkungan yang kondusif untuk perkembangan karakter santri Sekolah Islam Salaf Grikusumo dilakukan dengan menciptakan tradisi/pembiasaan praktis dalam kehidupan sehari-hari dalam segala aktivitas mereka sehari-hari dalam hubungannya dengan kualitas keberagamaan mereka maupun yang lainnya.

Nilai-nilai religius sedemikian ditanamkan kepada santri Sekolah Islam Salaf dalam kehidupan seharihari mereka. Pola penanaman nilai-nilai ini tercermin dalam pembiasaan shalat dhuha, tahajud bersama-sama, membaca Awrād Ratīb al-'Attas bersama-sama dalam setiap malam Minggu, shalat berjamaah dengan tepat waktu, ziarah kubur, dan mujahadah pada setiap malam Kamis.

Nilai-nilai luhur yang ditanamkan dalam proses pendidikan karakter siswa Sekolah Islam Salah meliputi banyak hal di antaranya yang tercermin dalam ketentuan tata tertib etika santri sebagai berikut:

Pertama, kedisiplinan waktu diajarkan kepada mereka melalui ketentuan aturan tata tertib, yang berisi: (1) berangkat tepat waktu dalam setiap

${ }^{16}$ Abin Syamsudin Makmun, Psikologi Kependidikan, (Bandung: Rosdakarya, 2002), h. 81. 
kegiatan pesantren maupun sekolah; (2) tidak boleh meninggalkan pesantren kecuali atas izin lurah pesantren atau pengurus yang berwenang; (3) diperbolehkannya pulang hanya setelah selesai imtihān (ujian) atau pada hari raya, atau karena uzur syar'i; (3) wajib berangkat jama'ah tepat setelah adzan berkumandang; dan (4) wajib mentaati jam malam bagi semua santri, yakni santri formal 22.00, dan santri salaf 23.00 WIB.

Kedua, karakter religiusitas tercermin dalam ketentuan tata tertib yang meliputi: (1) wajib mengikuti shalat berjama'ah di masjid untuk putera dan tidak diperkenankan keluar masjid kecuali setelah doa selesai; (2) dianjurkan melaksanakan secara rutin shalat sunnah Dhuha; (3) mengikuti bacaan wiridan (ratib al-'Attas) berjamaah pada malam Kamis; (4) mengikuti ziarah kubur pada hari Kamis sore untuk santri putra; (5) mengikuti dhiba'-an pada malam Jum'at; (6) mengikuti kegiatan ngaji pagi dan sore; (7) melaksanakan tugas-tugas kamar dan mengikuti ra'an.

Ketiga, karakter tertib diri dan kesopanan tercermin dalam ketentuan tata tertib yang meliputi: (1) berpakaian sesuai etika santri Islami; (2) dilarang berpenampilan seronok atau berlebihan; (3) berambut dan berkuku pendek serta rapi untuk putra, dan dilarang memotong rambut atau alis untuk putri; (4) dilarang membawa alat atau senjata tajam; (5) dilarang membawa HP, Tape, Radio atau barang-barang elektronok lainnya kecuali hari libur dengan tetap menjaga etika santri; (6) dilarang merokok di dalam kamar, masjid, gedung, dan di gedung-gedung sekolah untuk putra dan dilarang mutlak untuk putri; (7) dilarang keras mencoret-coret, mengotori dan memanjat pagar gedung manapun; (8) dilarang membawa atau mengkonsumsi minuman keras dan narkoba; (9) membawa atau membaca bukubuku berbau porno atau sejenisnya; (10) dilarang mangkal dan kongkokongko atau nongkrong di lokasi manapun.

Keempat, karakter pola pergaulan tercermin dalam ketentuan tata tertib sebagai berikut; menghormati yang besar dan welas asih terhadap yang kecil, berkata dan bersikap sopan terhadap siapapun, dilarang masuk kamar atau gotak lain tanpa seidzin penghuni masing-masing kamar, wajib mengucapkan salam ketika masuk kamar atau bertemu teman di jalan, dilarang membuat perkumpulan atau persengkongkolan dengan tujuan yang tidak baik, dilarang menggunakan milik orang lain kecuali atas izin pemiliknya, menjaga nama baik pesantren di manapun berada. 
Kelima, karakter peduli lingkungan hidup tercermin dalam ketentuan tata tertib yang meliputi; menjaga kebersihan pesantren dan sekitarnya, melaksanakan piket kebersihan, memelihara fasilitas-fasilitas yang ada, dilarang corat-coret di tembok, merusak yang fasilitas yang lainnya, mengembalikan segala peralatan ke tempat yang ditentukan, setelah usai digunakan, dilarang tidur di luar area bangunan pesantren, harus minta izin jika akan keluar dari kawasan pesantren dan khusus untuk putri keluar ke sekitar pesantren putri.

\section{Model Modeling dalam Pembentukan Karakter}

Penulis sepakat dengan pandangan bahwa pendidikan karakter memiliki persamaan dengan pendidikan nilai. Sehingga, ia juga merupakan pembentukan watak atau dalam kasus Sekolah Islam Salaf sebagai media pembentukan karakter dan watak seorang salaf-shalih melalui berbagai tahapan dalam proses pendidikan akhlak maupun nilai. Perbedaannya hanya sejauhmana perwatakan nilai itu dapat melekat dan konsisten pada diri santri sehingga menjadi watak, kepribadian atau karakter khas dia sebagai manusia dalam lingkungannya. Inilah barangkali baru kemudian disebut sebagai karakter setelah sebelumnya juga melalui pendidikan akhlak atau moral.

Usaha pembentukan watak melalui Sekolah Islam Salaf ini selain dengan pendidikan karakter di atas, secara berbarengan dapat pula dilakukan melalui pendidikan nilai dengan langkah-langkah sebagai berikut:

Pertama, menerapkan pendekatan "modelling" atau "exemplary" atau "uswah hasanah". Yakni mensosialisasikan dan membiasakan lingkungan sekolah untuk menghidupkan dan menegakkan nilai-nilai akhlak dan moral yang benar melalui model atau teladan. Setiap guru dan tenaga kependidikan lain di lingkungan sekolah memang didesain harus mampu menjadi "uswah hasanah" yang hidup (living exemplary) bagi setiap peserta didik. Bahkan, seorang guru didesain sebagai salah satu figur kharismatik yang memiliki penghargaan tersendiri dalam komunitas pembelajaran. Analogi Guru terhadap Murid bagai "Tuan terhadap hambanya", atau bagai "Hamba pada tuannya" dalam cara pandang bagaimana penghormatan (respek) yang patut diberikan kepada guru merupakan tata nilai yang telah melekat sedemikian kuat dalam tradisi Sekolah Islam Salaf dengan referensi kitab Talìm alMuta'allim yang diajarkan di sana. Sehingga, tata nilai ini memberikan 
konsekuensi guru adalah figur yang harus ditiru dapat memberi contoh yang baik pada santrinya.

Kedua, upaya menjelaskan atau mengklarifikasikan kepada peserta didik secara terus menerus tentang berbagai nilai yang baik dan yang buruk telah dilakukan di Sekolah Islam Salaf Girikusumo. Hal ini ditandai dengan intensitas pengajian kitab-kitab mengenai akhlak dan moral agama yang sangat tinggi baik melalui kegiatan intra maupun ekstra kurikuler sebagaimana dijelaskan pada bab berikutnya. Usaha ini dibarengi pula dengan tradisi respek atau memberi penghargaan (prizing) dan menumbuhsuburkan (cherising) nilai-nilai yang baik dan sebaliknya mengecam dan mencegah (discouraging) berlakunya nilai-nilai yang buruk; menegaskan nilai-nilai yang baik dan buruk secara terbuka dan kontinu dalam kehidupan mereka seharihari dan membiasakan bersikap dan bertindak atas niat dan prasangka baik (husn al-zhan) dan tujuan-tujuan ideal; membiasakan bersikap dan bertindak dengan pola-pola yang baik yang diulangi secara terus menerus dan konsisten.

Ketiga, SIS menerapkan pendidikan berdasarkan karakter (characterbased education). Hal ini dilakukan dengan menerapkan character-based approach ke dalam setiap mata pelajaran yang ada di samping matapelajaranmata pelajaran khusus untuk pendidikan karakter, seperti pelajaran agama, sirah, tasawuf dan sebagainya.

\section{G. Kesimpulan}

Meminjam teori Thomas Lickona, setidaknya ada tiga proses pendidikan karakter santri di Sekolah Islam Girikusumo, yang melibatkan aspek pengetahuan (cognitive), perasaan (feeling), dan tindakan (action). Ketiga aspek ini diinternalisasikan dalam tradisi pendidikan Sekolah Islam Salaf dengan pendekatan knowing the good, feeling the good, dan acting the good.

Pembentukan karakter santri Sekolah Islam Salaf Girikusumo dimulai dari pengajaran kognitif mengenai nilai-nilai kebaikan dan akhlak yang mulia kepada mereka. Pengenalan dan pemahaman kognitif tentang nilai-nilai yang hendak dibentuk menjadi karakter santri dilakukan baik dalam program kegiatan belajar mengajar di sekolah maupun dalam program ekstrakurikuler. 
Secara teoritik, salah satu faktor dominan yang mempengaruhi proses perkembangan karakter individu adalah faktor lingkungan (environment) yang merupakan kondisi yang memungkinkan berlangsungnya proses perkembangan karakter seseorang. ${ }^{17}$ Membentuk lingkungan yang kondusif untuk perkembangan karakter santri Sekolah Islam Salaf Grikusumo dilakukan dengan menciptakan tradisi/pembiasaan praktis dalam kehidupan sehari-hari dalam segala aktivitas mereka sehari-hari dalam hubungannya dengan kualitas keberagamaan mereka maupun yang lainnya.[w]

${ }^{17}$ Abin Syamsudin Makmun, Psikologi Kependidikan, (Bandung: Rosdakarya, 2002), h. 81

Walisongo, Volume 19, Nomor 2, November 2011 


\section{BIBLIOGRAFI}

Al-Qur'an dan Terjemahannya, Madinah: Lembaga Percetakan al-Qur'an Raja Fahd, $1418 \mathrm{H}$.

Anshori, Fuad, Membangun Paradigma Psikologi Islami, Yogyakarta: SIPRESS, 1994.

Arifin, M., Teori-teori Konseling Umum dan Agama, Jakarta: Golden Terayon, 1996.

Azra, Azyumardi, "Membangun Kembali Karakter Bangsa: Peran dan Tantangan Perguruan Tinggi," makalah disampaikan pada Dies Natalis ke-50 Universitas Gadjah Mada, 13 November 1999.

. "Pembinaan Pendidikan Akhlak Didik pada Era Reformasi," pokokpokok pikiran untuk Seminar tentang Pendidikan Anak dalam Indonesia Baru, Direktorat Pembinaan Pendidikan Islam pada Sekolah Umum, Depag RI, Jakarta, 2 November 1999.

"Catatan tentang Evaluasi atas Arah Pendidikan serta Fungsionalisasi Pemikiran Pendidikan di Indonesia," makalah pada Diskusi Ahli "Pendidikan Indonesia untuk Masa Depan yang Lebih Baik," Yayasan Fase Baru Indonesia, Jakarta, 25 Oktober 1999.

Paradigma Baru Pendidikan Nasional: Rekonstruksi dan Demokratisasi, Jakarta: Penerbit Kompas, 2003.

Baker, Anton dan Achmad Charris Zubair, Metodologi Penelitian Filsafat, Yogyakarta: Kanisus, 1990.

Bastaman, Hanna Djumhana, Integrasi Psikologi dengan Islam, Menuju Psikologi Islami, Yogyakarta: Pustaka Pelajar, 1997.

Bogdan dan Blinken, Qualitative Research for Education: an Introduction to Theory and Methods, Boston: Allin and Bacon. Inc, 1982.

Dzaky, Hamdani Bakran, Konseling dan Psikoterapi Islam, Yogyakarta: Fajar Pustaka Baru, 2001.

Durkheim, E., The Elementary Forms of Religious Life, New York: Free Press, 1965.

Faqih, Ainur Rahim, Bimbingan dan Konseling dalam Islam, Yogyakarta: UUI Press, 2001. 
Fraenkel, Jack R., How to Teach about Values: An Analytical Approach, Englewood, NJ: Prentice Hall, 1977.

Hawari, Dadang, Dimensi Religi dalam Praktek Psikiatri dan Psikologi, Jakarta: Balai Pustaka, 2002.

Indra, Hasbi Indra, Pesantren dan Transformasi Sosial, Jakarta: Penamadani, 2005. Ismail, Taufiq, et al., Drh., H., Membangun Kemandirian Umat di Pedesaan, Bogor: Pesantren Pertanian Darul Fallah, 2000.

International Education Foundation, "The Need for Character Education," makalah pada National Conference on Character Building, Jakarta, 25-26 November, 2000.

Jaya, Yahya, Bimbingan dan Konseling Agama Islam, Padang: Angkasa Raya, 2004.

Kirschenbaum, Howard \& Sydney B. Simon, "Values and Futures Movement in Education," dalam Alvin Toffler (ed.), Learning for Tomorrow: The Role of The Future in Education, New York: Random House, 1974.

Kumpulan Hasil-Hasil Kongres Ummat Islam Indonesia: Menyongsong Era Indonesia Baru, Jakarta: MUI, 1998.

Mastuhu, Dinamika Sistem Pendidikan Pesantren, Jakarta: INIS, 1994.

Muhammad Azis, Abdul Ghoffar Muhammad Azis, et al., DR., Dirāsāt al-Nizhām wa '-Tsaqāfah al-Islämiyyah, Kairo: Al-Azhar University, tth.

Nandika, Dodi, Pendidikan di Tengah Gelombang Perubahan, Jakarta: Pustaka LP3ES, 2007.

Miles, Matthew B. dan A. Michael Huberman, Qualitative Data Analysis, Baverly Hills, Sage Publication, 1986.

Mubarok, Ahmad, Konseling Agama Teori dan Kasus, Jakarta: Bina Rena Pariwara, 2000.

Musnamar, Thoha, Dasar-dasar Konseptual Bimbingan dan Konseling Islami, Yogyakarta : UII Press, 1992.

Muthohhari, Murtadha, Perpsektif al-Quran tentang Manusia dan Agama Bandung: Mizan, 1992.

Natsir, M., Kubu Pertahana Mental dari Abad ke Abad, Jakarta: DDII perwakilan Jatim, 1969.

Prayitno dan Erman Amti, Dasar-dasar Bimbingan dan Konseling, Jakarta : Rineka Cipta, 2004. 
Qardhawi, Yusuf, Anatomi Masyarakat Islam, terj. Setiawan Budi Utomo Jakarta: Pustaka al-Kautsar, 1999.

Shihab, M. Quraish, Wawasan al-Qur'an: Tafsir Maudhu'i atas Pelbagai Persoalan Umat, Bandung: Mizan, 1996.

Republika , Rabu, 25 Agustus 2010.

Website:

http://www.serambinews.com/news/view/29630/tasawuf-pendidikan

http://www.jurnalnet.com/konten.php?nama=popular\&topik=10\&id=167

http://charactercounts.org/training/cds-schedule.php

Akhmad Sudrajat, "Pembinaan Pendidikan Karakter di Sekolah Menengah Pertama," dalam http://akhmadsudrajat.wordpress.com/2010/09/15/ konsep-pendidikan-karakter/Kemendiknas. 2010.

Meliala, Adrianus \& Iqrak Sulhin, "Analisis Kriminalitas Akhir Tahun 2007”, dalam http://kriminologi1.wordpress.com/, diakses tanggal 10 Juni 2010.

Mustofa, Muhammad, "Pemulihan Hak-hak Sipil Mantan Napi," dalam http://kriminologi1.wordpress.com/, diakses tanggal 10 Juni 2010.

Pembinaan bagi Tahanan \& Napi, http: //hukumham info/index. php? option=com _content\&task=view\&id=75\&Itemid=50, diakses tanggal 10 Juni 2010.

Riwayat, Bimbingan dan Konseling Islami, http://www.blogger.com/emailpostg?blogID=4862653753991080683\&postID=4727569541395182971, diakses tanggal 10 Juni 2010.

Silaban, Elli Hakim, Menilik Kasus Pembunuhan Orang Tua Terhadap Anak, dalam http://www.silaban.net/2002/07/28/menilik-kasus-pembunuhanorang-tua-terhadap-anak/, diakses tanggal 10 Juni 2010. 